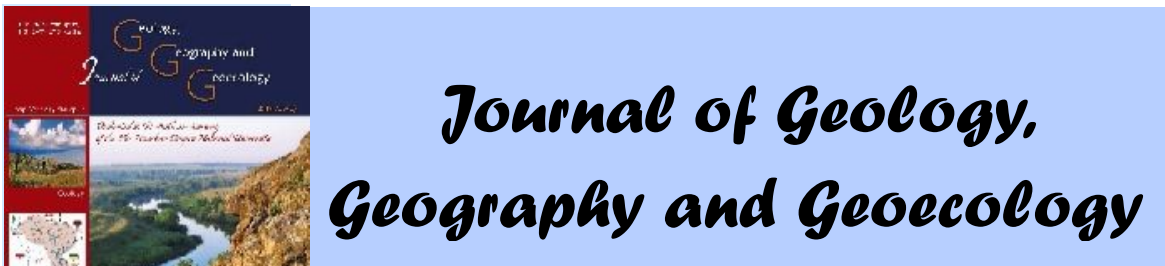

Journal home page: geology-dnu-dp.ua

Journ.Geol.Geograph. Geoecology, 27(2), 357-367 doi: $10.15421 / 111860$

\title{
Natural-historical and ecological analysis of land resources and land use in Lugansk region
}

\author{
D. Sopov ${ }^{1}$, N. Sopova ${ }^{2}$, O. Dankeyeva ${ }^{3}$, S. Chuhaiev $^{4}$ \\ Lugansk National Agrarian University, Kharkov, Ukraine, e-mail:Inau.sopov@gmail.com ${ }^{1}$,Inau.sopova@gmail.com², \\ dankeeva.olga@gmail.com ${ }^{3}$,agro.chugayev@gmail.com ${ }^{4}$
}

Received 14.07.2018;

Received in revised form 07.08.2018; Accepted 04.10.2018

suggest some adjustments to land management and land use policies. The influence of human economic activity (in particular, agriculture and the coal industry) on the nature of land use in the Lugansk region is considered (separately for the right bank and the left bank part thereof). The significance of the extent of ravines in the territory and the surface washout in the process of degradation of soils and lands is emphasized, which is especially expressed on the Donetsk ridge (right bank of the River Seversky Donets). The role of the semi-mountainous terrain of the Donetsk ridge as a natural factor in the spread of erosion processes is noted. A brief historical review of attempts to combat the development of ravines in Lugansk region, which have been conducted since the second half of the nineteenth century, is presented, but the vast majority of these efforts were not effective. One of the negative factors that influenced the structure of land use is the removal of an increasingly large area from use as grazing land, which increases the intensity of erosion processes. The destructive influence of mine production on the structure of land use in the studied region is highlighted. We note the ecological consequences of physical alienation of lands as a result of their occupation by waste heaps and other anthropogenic forms of relief, formed by the mining industry. It is emphasized that not only the mines themselves, but also concentration of factories, communication structures, etc. play a role in reducing the area occupied by agricultural land, and therefore cause a negative change in the structure of land use in the right-bank part of the territory of Lugansk region. It is noted that extensive and excessive intensive land use in agriculture and the coal mining industry in Lugansk region have led to the degradation of large areas of land and impoverishment of the land fund. It is stressed that the current structure of land use requires radical changes which should be based on new conceptual principles and a systematic approach to the problems of nature management.

Key words: land resources, land fund, land plot structure, land use structure, land management, land degradation, landfill, extensive use of land, nature use.

\section{риродно-історичний т екологічний н ліз земельних ресурсів т землекористув ння в уг нській обл сті}

• опов $^{1}$, . . опов ${ }^{2}$, .

уг нський н ціон льний гр рний університет, pків, кр їн, e-mail:Inau.sopov@gmail.com ${ }^{1}$, lnau.sopova@gmail.com ${ }^{2}$,dankeeva.olga@gmail.com ${ }^{3}$, agro.chugayev@gmail.com ${ }^{4}$

ед внє, ле інтенсивне господ рське освоєння кр ю призвело до формув ння суч сної структури землекористув ння, зумовленої як природними, т к і історичними ф ктор ми. еструктивний нтропогенний вплив н геоморфосферу призвів до дегр д ції грунтів і зубожіння земельного фонду. етроспективний н ліз порушеної у роботі проблеми дозволяє виявити причини т н слідки уст леної в регіоні системи землекористув ння $\mathrm{T}$ вносити певні корективи в політику землевпорядкув ння т землекористув ння. озглянуто вплив господ рської діяльності людини (зокрем , сільського господ рств т вугільної промисловості) н х р ктер землекористув ння в уг нській обл сті (окремо для пр вобережної т лівобережної її ч стин). голошено н зн ченні з яруженості території й площинного змиву в процесі дегр д ції грунтів і земель, що особливо вир жено н онецькому кряжі (пр вобережжі іверського інця). ідзн чено роль н півгірського рельєфу онецького кряж як природного чинник поширення ерозійних процесів. ведено короткий історичний огляд спроб боротьби з розвитком ярів н $\quad$ уг нщині, які проводилися, почин ючи ще з другої половини ст., ле в перев жній більшості не були ефективними. к один із нег тивних чинників, що вплинули н структуру землекористув ння, окреслено відведення дед лі більшої площі під п совищ , що підвищує інтенсивність ерозійних процесів. исвітлено згубний вплив 
ш хтного виробництв н структуру землекористув ння в досліджув ному регіоні. ув жено щодо екологічних н слідків фізичного відчуження земель вн слідок їх з йняття породними відв л ми, терикон ми т іншими нтропогенними форм ми рельєфу, утвореними гірничопромисловою діяльністю. ідкреслено, що не лише вл сне ш хти, й зб г чув льні ф брики, комунік ційні споруди тощо відігр ють певну роль у зменшенні площ, з йнятих сільськогоспод рськими угіддями, отже виклик ють нег тивні зміни структури землекористув ння у пр вобережній ч стині території уг нської обл сті.

ідзн чено, що екстенсивне, т кож н дміру інтенсивне землекористув ння в сільському господ рстві т вуглевидобувній промисловості в уг нській обл сті призвели до дегр д ції великих площ земель т зубожіння земельного фонду.

голошено, що сформов н структур землекористув ння потребує р дик льних змін, які б м ли 6 зув тися н нових концепту льних принцип х і системному підході до проблем природокористув ння.

лючові слов : земельні ресурси, земельний фонд, структур земельних угідь, структур землекористув ння, землевпорядкув ння, дегр д ція земель, площинний змив, екстенсивне використ ння земель, природокористув ння.

Introduction. Problem setting. Land resources are the most important part of the natural environment, which predetermine the existence and use of all other natural resources. At the core of all types of nature management is the land use system, which is formed under the influence of natural, historical, ethno-cultural, socio-economic factors, which lead to a combination of different areas of land use and the formation of a particular ecological situation.

Extensive methods of using natural resources, including land, have led to the development of a number of destructive processes, the deterioration of environmental quality of the environment and unidirectional land use.

In Lugansk region an almost practically catastrophic situation has developed in the area of land use associated with intense violent use of land in agriculture and the mining industry.

Economic development of the eastern territories of Ukraine began later than the rest of its territories and took place quite intensively. The heterogeneity of the natural conditions of various parts of the modern Lugansk region caused differences in the nature of management, and, consequently, different pressures on the natural environment, in particular, on land resources. The nature of the relief and climatic features of the left bankof the River Seversky Donets led to the development of agriculture, intensive ploughing of land with all the negative consequences. On the right bank of the River Seversky Donets, in addition, due to the unique geological structure of the area, the mining industry has concentrated again, with significant negative environmental consequences. The main pressure fell on the geomorphosphere, or more precisely, on the pedosphere - due to reduced agricultural use, soil degradation, fertility decline, physical reduction in the area of fertile soils, deterioration of the physical and chemical properties of the soils, and consequently - loss of crop, pollution of all components of the natural environment, deterioration of the sanitary and hygienic living conditions of the population, etc. That is, a number of environmental problems arose, which for
Lugansk region, in the current conditions, have become a matter of special urgency.

The land use structure requires radical changes not only because of the impoverishment of land due to inefficient use of the land fund, but also due to the destructive events in the region associated with the recent war and the temporary Russian occupation of part of the territory of Lugansk region, which together have led to tragic consequences both in society and in the natural environment.

A retrospective and up-to-date view of these problems can reveal the causes and consequences of the existing land management and land use system and make constructive conclusions.

The above mentioned postulates lead to the relevance of the chosen topic of study.

The purpose of the work is the natural-historical and ecological analysis of land resources and land use in Lugansk region, identifying the causes and consequences of the impoverishment of the land fund - the basis of the socio-economic development of the region.

\section{Tasks that were delivered:}

- to identify and analyze the influence of natural-historical conditions of the region on the formation of land use structure;

- to make a description of the structure of land use and its changes in time;

- to create a base of basic indicators that reflect the state of land use and trends in its changes;

- to determine the nature of the negative impact of existing approaches to land use in the region;

- to substantiate practical recommendations aimed at optimizing the land use structure in the region.

The object of scientific research is the land resources of the Lugansk region.

The subject of scientific research is the structure of land use, its changes over time, in particular the state of land used in agriculture and industry.

The methodological basis of scientific research is the laws and principles of dialectics; the basic methodological basis is the systematic approach as 
a means of studying the interconnections and interdependencies in the system of nature - society. In conducting this research, we use such methods as logical (analysis, synthesis, comparison, deduction, induction), historical-geographical, mathematicalstatistical, descriptive, cartographic, cardometric.

The novelty of the scientific research lies in the geographic approach to the study of land use in Lugansk region - a region that has been overexploited by economic development, excessive agricultural pressure on landscapes and destruction of the natural environment for the development of the coal mining industry.

The practical value of scientific work is to critically evaluate the current structure of land use in agriculture and industry; identifying the causes and trends of its changes; identification of ways to optimize the land use structure for the conservation and rational use of the natural resources of the region.

The main material of scientific research. Lugansk region, which is the territory of our scientific research, is located in the far east of Ukraine. Even the visual analysis of a physical map (Fig. 1) proves the spatial heterogeneity of its surface. The territory of the region is clearly divided by its main water artery - the River Seversky Donets - into the left bank and the right bank. In the morphostructural plan, the left bank is represented by the Starobelskaya plain (the southern spurs of the Central Russian Highland), which was formed on the ancient foundation of the Voronezh anteclase. The Starobelskaya plain is dissected by river valleys of submeridional stretching and ravines. Here on the Cretaceous-marl rocks a soil cover formed, represented by ordinary black soils.

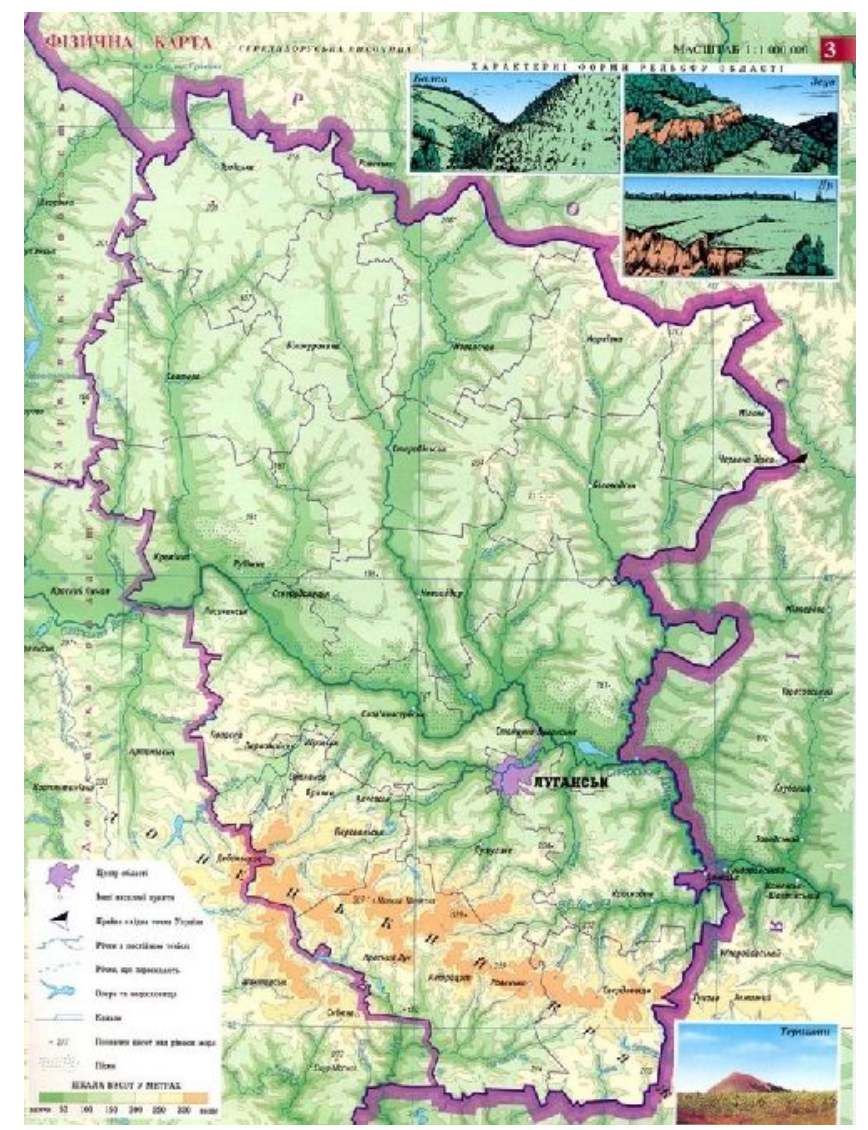

Fig. 1. Physical map of Lugansk region

The right bank of the south of the studied region is represented by the Donetsk hills, which within the Lugansk region is the northern macroslope of the Donetsk ridge, the main Donetsk watershed, and, in part, the southern macroslope of the Cretaceous. This morphostructure due to the specific tectonic processes that took place in geological antiquity is characterized by the complex and original relief of the structuraldenudation plain - a distinct alternation of the basins in the watersheds, where typical black soil types were formed on forest non-carbonate rocks. Significant vertical and horizontal fractioning of the surface associated with the tectonic activity of individual areas of the territory and active geomorphological (first and foremost, erosive) processes led to the formation of slopes of different steepness, in which later, due to human economic activity, negative geomorphological processes became accelerated. 
In the abovementioned morphostructures, depending on the characteristics of the relief and regional climatic differences, various types of land have been formed - water divisions, watershed slopes, ravine slopes, floodplains, etc.

The nature of lands depends on many natural factors, among which geological (determining role of the parent rock), climatic (temperature regime and humidity), as well as morphometric characteristics of the relief occupy a significant place.

The investigated region is located in a temperate climatic zone, and its geographic location results in a large amount of heat flow: on the left bank of Lugansk region, the average annual total solar radiation is $95-110 \mathrm{kcal} / \mathrm{cm}^{2}$, on the right bank of Lugansk region - 105-114 kcal / $\mathrm{cm}^{2}$ (Atlas prirodnih usloviy $i$ estestvennyih resursov Ukrainskoy SSR, 1978).

The climatic conditions of the left bank of Lugansk region are characterized by features of latitudinal zonation, on the right bank of Lugansk region the increased and strongly dissected relief creates certain azonal features of the climate (Table $1)$.

Table 1. Main climatic characteristics of the study area (Atlas prirodnih usloviy i estestvennyih resursov Ukrainskoy SSR, 1978)

\begin{tabular}{|c|c|c|c|c|}
\hline The region & $\begin{array}{c}\text { Average annual } \\
\text { temperatures }\end{array}$ & $\begin{array}{c}\text { Average January } \\
\text { temperatures }\end{array}$ & $\begin{array}{c}\text { Average July } \\
\text { temperatures }\end{array}$ & $\begin{array}{c}\text { Average annual } \\
\text { rainfall }\end{array}$ \\
\hline $\begin{array}{c}\text { Left bank of the } \\
\text { Lugansk region }\end{array}$ & $+7^{\circ}$ & $-7,-8^{\circ}$ & $+21,+22^{\circ}$ & $450-500 \mathrm{~mm}$ \\
\hline $\begin{array}{c}\text { Right bank of the } \\
\text { Lugansk region }\end{array}$ & $+6,+7^{\circ}$ & $-6,-7^{\circ}$ & $+21,+22^{\circ}$ & $500-550 \mathrm{~mm}$ \\
\hline
\end{tabular}

The amount of rainfall in the Lugansk region, fluctuating within considerable limits, both seasonally and geographically, depends to a large extent on the degree of fractioning of the area and the exposure of the slopes. The most humid part of the region is the Donetsk ridge, especially the main Donetsk watershed and the southwest macro slope, where more than 500-550 mm falls per year. Thus, the orographic factor creates significant azonal deviations in the hydrothermal regime of the territory. The relatively large amounts of rainfall on the Donetsk ridge creates favourable conditions for the spread of water erosion, especially since in the warm period rainfall is twice as high as in winter, and the intensity of summer precipitation far exceeds that of winter.

The territory of Lugansk region can be called the region of both the old and the newest economic development. On the one hand, almost three thousand years ago, various nomadic tribes inhabited from what is now Lugansk region, and in the beginning of our era our people settled on the path of transition from nomadic pastoralism to sedentary agriculture. However, this ancient economic development had a minimal impact on the state of the natural environment, since the land was used mainly for pasture and hay and - to a much lesser extent - for cultivation of crops, and was interrupted by the invasion of aggressive nomads.

For thousands of years now, Lugansk region had almost no permanent population, actually becoming a «Wild Field», which contributed to preserving the primitive steppe and forest (flood and ravine forests) landscapes, which existed even when the lands of the Dnieper Ukraine were agrolandscapes.

A new stage in the development of the territory (mainly agricultural, but also associated with the extraction of iron and copper ores) began in the late 16th and early 17th centuries, when Lugansk region from the west was gradually settled by Ukrainian peasants and cossacks, from the east by the Don cossacks, and from the north -«people who had served in the army». But the predominant nature of land use until the end of the 18th century was agricultural production.

Economic development of the lands of the modern Lugansk region began with agriculture, which was associated with favourable natural conditions and rich natural resources - temperate climate, fertile lands, large areas of forests adjacent to the valleys of navigable rivers and large ravines.

The bulk of the inhabitants of the Slobozhanshchyna and the Donetsk steppes were engaged in working the land. There were two systems of farming: the three-field system and the cross-flow system. In the presence of large reserves of land, the peasants used a cross-flow system, which was gradually replaced by the three-field system, in which the land was divided into three parts: two of them were cultivated and sown, and the third was left fallow. Subsequently, alternation of tilled sites took place. After two years of cultivation, the land for the third year remained free, «resting» (Podov, 2004). Such a system was due to the fact that there was plenty of land, and there was no sense in tackling the problem of preserving its fertility.

In the first half of the eighteenth century, only a small part of the land was cultivated. As the 
settlement and development of the territory increased from the middle of this century, the crop area began to expand. The peasants were thrown onto waste land, moving to new, virgin lands. Gradually, the area of tilled land moved on the slopes of river valleys and large gullies, and broke the ground floor. Steppe fires and unregulated cattle grazing led to a disturbance of the turf cover, physical extinction of land under building, roads and so on. Extensive forms of land tenure led to a low yield of grain crops.

The systematic impact of man on the environment was amplified, which served as a forerunner of the imbalance in the landscapes of the region. This was especially noticeable on the land, as the most vulnerable component of the natural environment.

Since the beginning of the economic development of the present-day territory of Lugansk region, the land began to collapse. According to the general survey conducted in 17891804 , and presumably up to 1861 , the extent of cultivation in the territory did not exceed $1-2 \%$ (Fondovi materialy Derzhavnogo regional'nogo geologorozviduval'nogo pidpryjemstva «ShidDRGP», 2014). After the reform of 1861, the mass settlement of our region began, resulting in a sharp increase in the area of arable land, which by the end of the nineteenth century had already reached 3.1 $4.5 \%$ (Lyashenko, 1952). And at that time there were first signs of the destruction of land. Thus, at the beginning of the formation of the agrarian economy in the territory of our region (within the limits of the modern administrative area), specialists counted about a thousand gullies.

After the reform of 1861, the rapid development of industry began in the province. This was facilitated by the presence of enormous natural resources, which at that time were not only explored, but already developed. In 1722, deposits of coal were discovered in the present Lysychansk area. A little later ore was discovered and the first blast furnaces built, which were soon abandoned.

However, the qualitative structure of nature on the territory of Lugansk began to change, because of the spread of coal mining. At this stage, human activity in the natural environment was leading to significant changes.

With the discovery of coal deposits, this region began to be formed as an industrial one, which had a certain imprint on the structure of land. After all, the area of land unsuitable for agricultural use increased due to both underground workings and ploughing of the land.

In 1871, outstanding researcher I. F. Levakivsky noted that in the Lisichansk region of the Bahmut district «there are plenty of ravines, they occupy an area of up to 40 dessiatins out of the total the area of the estate of 648 dessiatins, not counting balkis ...» (Levakovskij, 1871). Since there is no reason not to suppose that this area was atypical for the entire Lisichansk region, both naturally and in terms of development, we assume that the area occupied by ravines was at that time already more than $6 \%$ of the entire region. And the plundering of new territories, mainly of sloping lands, the formation of numerous boundary structures, field roads led to further acceleration of erosion processes.

The agricultural development of the lands in Lugansk region has its historical reasons. This was an increase in the demand for and export of bread and the further growth of the population of the region, which inevitably led to an increase in the area of arable land, and hence - to the destruction of natural vegetation, reduction of the areas of virgin steppes, which in turn led to the emergence and strengthening of erosion processes: natural erosion, which was caused only by natural factors and not of a catastrophic nature, received a powerful impetus and changed to a more intense accelerated or anthropogenic process.

Due to the development of coal mining, the southern part of the Lugansk region was populated more intensively, and on the Donetsk ridge, where virgin steppes were confined to the watersheds with developed ridges and hollow relief, the hollows and slopes were exploited, which contributed to the further development of erosion processes. I. F.Levakivsky noted that the most depleted slopes with washed- out soils and gulleys were distributed near settlements, which clearly testifies to their anthropogenic origin (Levakovskij, 1871).

The tilling of new and new territories, including the slopes, the creation of numerous boundaries led to the further development of accelerated erosion. I. F. Levakivsky gives the following example: «In 1890, in the autumn, a boundary ditch was dug in the direction of the slope; by the autumn of 1891 , a moat of about 40 sazhan in length two-quarters of its depth and the same width had formed from this trench» (Levakovskij, 1871). It was near the NagolnoTarasivske village, located in the central part of the Donetsk ridge.

In the northern part of Lugansk region (that is, on the left bank), which, from the middle of the XVII century, was populated mainly by people from the Zadnieper Ukraine, the settlements concentrated along rivers and large ravines ( balkis). Since there were no mineral deposits there yet, the peasants raised grain, vegetables and bred cattle. The long-term erosive fractioning of the land here began to increase due to human economic 
activity, and the steppes retreated to the watersheds, natural rich pastures suffered intensive and unregulated grazing of cattle, on the slopes erosion took place and gullies formed.

The formation of gullies became more and more intensified due to the fact that the lands were affected by erosion, the peasants took over new areas, the so-called «wastelands», but also the erosion processes did not stop on the abandoned lands because there was already a shift of soil through the destruction of the turf cover, mainly on sloping surfaces.

An unimaginable and unreasonable ploughing with all the consequences «has a historic prescription and its historical reasons: first, the possibility of selling grain crops and their continuously growing exports, and further population growth - led to the continuous increase in the area under the plough» (Lyashenko, 1952). The increase in the area of arable land led to the destruction of natural vegetation, reduction of virgin steppes, which further intensified erosion processes (natural erosion changed to more intensive accelerated or anthropogenic erosion).

In the Donbass, where virgin steppes were confined to watersheds with ridges and ridges and hollow relief, the hollows, and slopes were exploited, which again contributed to the development of erosion processes. V. I. Taliyev (Taliev, 1896) noted that most of the depleted slopes with washed-out soils are found near settlements, which is further evidence of the anthropogenic origin of erosion. The same idea was stated by E. M. Lavrenko, who linked the existence of large areas of stony empty lands with environmentally unfriendly human activities (Lavrenko, 1926).

The abandoned eroded lands, which were previously under cultivation, were destroyed . Unregulated cattle grazing had a fatal influence on the state of the turf cover. Even in hilly forests that play a reclamation role and contain rich feed resources, cattle grazing led to a disturbance in the turf cover, washing away of forest soils, exposure of the root system of trees and shrubs, young growth was eaten by cattle, the forests were disturbed, gradually losing their water conservation and forest-melioration value. The names of some ravines - Gorihova, Lipova and others - indicate the destruction of forests in order to increase the area of arable, garden and meadow lands. On the slopes of these ravines so-called «unfit» land formed. There is no indication of nut and lime wood vegetation.

The solid runoff that has increased as a result of erosion has aggravated the hydrogeological conditions of the once navigable Donbas rivers. Erosional runoff, which in large quantities is carried out from ravines and gullies, caused silting of rivers, waterlogging them in some areas. And the surface runoff from the ploughed slopes reduced the humus horizon and worsened the quality of soils.

In particular, the archival materials of the report of the forestry director V. Reykha, the director of the Lugansk Sand and Gulley district of the Donetsk Land Department in 1918, testify to the problems of the Donbass in general: «It is too well known to everyone that the growth of gullies causes inconvenience to the plowman, the. In particular, in our area, they are simply a problem for any peasant, because it is absolutely impossible to find any roads in the area which are not slashed by this or that ravine. According to the survey, I can say that in our district there are about 3 thousand gullies which steal land the peasants, almost a tenth of the total land in the district, that is about 34 thousand dessiatin» (Derzhavnij arhiv Luganskoyi oblasti).

Another «Report on the accelerated formation of gullies in the past, present and future» by 1918 (Pirko, 2003) also noted that, according to the survey, Slavyanoserbsk region had more than 3 000 gullies areas occupying over 3000 dessiatin.

The fractioning of the growing area and the growth of areas unsuitable for agricultural use caused a decrease in ploughing. The misfortune caused by the ravines became so significant that they were one of the causes of the poor crop yield. In particular, the reason for the crop failure in 1891, which covered twenty of the best grain-producing provinces of the Russian Empire, «many believed ... drainage and destructive action of the ravines» (Shikula, 1961), which gradually formed from the previous economy. Destruction of any woody vegetation in the steppe areas and the ploughing of steep slopes of valleys and ravines led to a decrease in moisture in the soil.

It should be noted that the intensification of erosion processes in the province began in the second half of the nineteenth century, that is, much later than in the whole of European Russia. Intensive tillage, inappropriate agricultural equipment, fragmentation in combination with peculiar natural conditions (significant fractioning by spread of the long established erosion area, large areas of steep slopes, weak resistance to soil erosion, the nature of precipitation, etc.) caused such a rate of development of erosion that by 1917 the situation had become catastrophic. In order to maximize the benefits of land at minimum cost, eroded plots were abandoned and new ones taken up, which was not something new in the then landuse system. «Unsuitable» land used for grazing livestock, turned into stony wasteland and was finally removed from household use. Thus, the 
increase in the area of agricultural land eventually led to its reduction.

The semi-mountainous nature of the relief of the right bank of Lugansk region, especially its highest part - the Donetsk ridge, was not favourable for agricultural development, and therefore, for a long time, there were no numerous permanent rural populations here. Yet, the right bank of Lugansk region with some delay, still experienced the same changes in the landscape of the environment as the left bank, which was also associated with agricultural development of the territory. Naturally, despite the development of the mining industry prevailing on the right bank of Lugansk region and agricultural production, it also played a role in the degradation of the land fund. Fertile black soils, confined to the main Donetsk watershed, were intensively exploited, which, together with the negative natural processes, could not fail to provoke their rather rapid decrease in soil fertility. The lands have undergone a massive violent agricultural load. As a result of the combined effects of various anthropogenic factors, there is a greater transformation of the natural environment, and hence the environmental stress on land resources is greater.

It cannot be argued that no attempts were made to improve the situation, but they were local in nature. All attempts to counter the effect of erosion by means of planting forests without combining them with agrotechnical measures proved ineffective (Fondovi materialy Derzhavnogo regional'nogo geologorozviduval'nogo pidpryjemstva «ShidDRGP», 2014). The main task - a comprehensive regulation of runoff and protection of soils throughout the entire catchment area - remained unresolved.

M. A. Rozov noted that on the Donetsk ridge a whole complex of extremely favourable conditions and reasons for erosion was formed. In his opinion, Lugansk region was the area with the most ravines: «... the uplands that diversify the relief, intensive plowing, the lack of forests, also the pronounced continental climate - all this contributed to the formation of many gullies» (Rozov, 1927).

This assessment of the territory of the Donbas in the erosive aspect is confirmed by E. E. Kern, who distinguished Ekaterinoslav province, and especially the Bahmut region, as an area with a lot of ravines. In many areas, he wrote, «the land under ravines was from 5 to $30 \%$ of the total area» (Kern, 1928).

After the Second World War, anti-erosion measures were carried out on a limited scale and limited to reclamation. Their effect was insignificant because of the ploughing up of «virgin» lands. Further measures were not effective; there was no systematic fight against erosion in the Donbas.

Environmental conditions in our region unfavourable to agriculture and the high level of economic development have led to an aggravation of the problems of rational, ecologically sustainable use of natural resources, protection and reclamation of land in one of the old industrial regions of Ukraine - Donbass, which includes almost half of the territory of Lugansk region.

It is known that in the case of extensive economic management, the structure of land use, which has been formed for a long time, is often violated; in particular, the ratio of stabilizing and destabilizing components of the land fund changes.

According to statistical materials (FondovimaterialyGolovnogoupravlinnjaDerzhgeokadastruvLugans 'kijoblasti, 2016), the lands of Lugansk region are divided into agricultural land, forests and forest cover, built- up land, open wetlands and dry lands with special vegetation. The area of agricultural land is $73.3 \%$ of the total territory of the administrative region. Cultivated land accounts for $97,6 \%$ of the agricultural land. In turn, in the structure of agricultural land, tilled land occupies $66.6 \%$.

Purely natural and sustainable are forests; under certain conditions relatively stable stands are planted forests, hayfields and pastures. Lands which should be considered unstable are those that, having undergone to some extent the influence of human economic activity, have experienced a significant transformation, changed their properties (arable land, forest park areas, etc.).

The structure of the land consists primarily of agricultural land, the area occupied by forest, pastures, meadows, marshes (Table 2). The correlation between them in different physicalgeographical and historical conditions may be different, and this is determined by their stability.

In the scientific agrarian literature, in addition to such an indicator as the stability of the land, environmentally stabilizing and destabilizing lands are also distinguished.

Among the aforementioned types of lands, the lands which stabilize the environment include hayfields, those which we consider destabilizing include pastures and arable land, which are most affected by mechanical (pasture) and agro-technical (arable) pressure. Our calculations found that the ratio between them is $1: 3$.

Thus, we arrive at the conclusion that in the ratio of agricultural lands in Lugansk region destabilizing components prevail, mainly arable land. 
Table 2. The structure of the land fund of Lugansk region at the beginning of 2016 (Fondovi materialy Golovnogo upravlinnja Derzhgeokadastru v Lugans'kij oblasti, 2016)

\begin{tabular}{|c|l|c|}
\hline № & Type of the land & Area (thousand hectares) \\
\hline 1 & Agricultural land & 1955.75 \\
\hline 2 & Forests and other forest areas & 356.28 \\
\hline 3 & Land of nature conservation designation & 128.46 \\
\hline 4 & Open wetlands & 16.56 \\
\hline 5 & Lands under recreational designation & 188.15 \\
\hline 6 & Built-up land & 22.06 \\
\hline 7 & Dry open lands of various types & 1.10 \\
\hline 8 & Total area & 2668.37 \\
\hline
\end{tabular}

Thus, the analysis of the structure of the land resources of Lugansk region shows the high agricultural development of the territory, insignificant forest cover and the obvious imbalance between the lands that are in intensive agricultural use and the environment of stabilizing natural lands.

In absolute terms, the level of agricultural land cultivation in Lugansk region significantly exceeds the calculated norm. According to V. Medvedev and $\mathrm{S}$. Buligin, the maximum permissible level of cultivation, expressed in an entropy measure, is $38.2 \%$ (Medvedyev, 1992). In Lugansk region, it exceeds the calculated almost twice, and the continued trend is to increase the area of arable land.

But it is especially dangerous to increase the area of agricultural land, in particular arable land, on erosion-prone slopes with a steepness of more than $2^{\circ}$ (Table 3 ).

Table 3. Distribution of agricultural lands on slopes of different steepness (Fondovi materialy Golovnogo upravlinnja Derzhgeokadastru v Lugans'kij oblasti, 2016)

\begin{tabular}{|c|c|c|c|c|c|c|}
\hline \multirow{2}{*}{ Year } & Kind of land & $\begin{array}{c}\text { Slope steep- } \\
\text { ness } \\
0-2^{\circ}\end{array}$ & $\begin{array}{c}\text { Slope steep- } \\
\text { ness } \\
2-5^{\circ}\end{array}$ & $\begin{array}{c}\text { Slope steep- } \\
\text { ness } \\
5-10\end{array}$ & $\begin{array}{c}\text { Slope steep- } \\
\text { ness } \\
10-15^{\circ}\end{array}$ & $\begin{array}{c}\text { Slope steep- } \\
\text { ness } \\
>15^{\circ}\end{array}$ \\
\hline \multirow{2}{*}{1972} & Agricultural land & $17.88 \%$ & $34.73 \%$ & $1.78 \%$ & $1.37 \%$ & $0.04 \%$ \\
\cline { 2 - 7 } & tilled land & $20.95 \%$ & $33.17 \%$ & $0.74 \%$ & $0.02 \%$ & - \\
\hline \multirow{2}{*}{1982} & Agricultural land & $49.59 \%$ & $45.23 \%$ & $4.96 \%$ & $1.01 \%$ & $0.05 \%$ \\
\cline { 2 - 7 } & tilled land & $54.8 \%$ & $43.74 \%$ & $1.36 \%$ & $0.01 \%$ & - \\
\hline \multirow{2}{*}{1998} & Agricultural land & $53.75 \%$ & $37.37 \%$ & $7.05 \%$ & $0.86 \%$ & $0.15 \%$ \\
\cline { 2 - 7 } & tilled land & $26.89 \%$ & $57.25 \%$ & $14.69 \%$ & $0.18 \%$ & - \\
\hline
\end{tabular}

From the table it follows that the area of agricultural land on the slopes from $5^{\circ}$ to $10^{\circ}$ over 26 years increased by $5.27 \%$, and on the slopes over $15^{\circ}$ - by $0.11 \%$. The area of tilled land increased by $6 \%$ at predetermined areas, on erosionhazardous (slope over $2^{\circ}$ ) - by $24 \%$, and on catastrophically erosion-hazardous (steepness of 10 - 15 $\left.{ }^{\circ}\right)$ - by $0.16 \%$. The result is that in the 35 years (1965 - 2001), the area of eroded arable land in the Lugansk region increased from $54.7 \%$ to $66.5 \%$, which is more than twice the national average. At the same time, the erosion of the steep slopes reached critical, even catastrophic, magnitudes (Table 4).

Table 4. Erosion of arable land on slopes of different steepness in Lugansk region by \% (Fondovi materialy Golovnogo upravlinnja Derzhgeokadastru v Lugans'kij oblasti, 2016)

\begin{tabular}{|c|c|c|c|c|c|}
\hline \multicolumn{6}{|c|}{ Total eroded tilled land on slopes with different steepness, \% } \\
\hline $0-1^{\circ}$ & $1-2^{\circ}$ & $2-3^{\circ}$ & $3-5^{\circ}$ & $5-7^{\circ}$ & $>7^{\circ}$ \\
\hline 33.83 & 57.80 & 95.14 & 98.40 & 98.40 & 98.27 \\
\hline
\end{tabular}

The structure of the land is also changing due to the development of linear erosion, the formation of gullies, which is greatly facilitated by geological and geomorphological conditions in conjunction with climatic conditions.

For a long time, the structure of agricultural land has changed due to the removal of part of it for industrial and social needs. Changes to some extent have also concerned arable land, the qualitative state of which has deteriorated due to the cultivation of steep slopes with a washed out layer of soil.

The qualitative state of agricultural lands directly depends on the structure of the land fund itself (Table 5).

It is known that the area of surface washout leads to a decrease in soil fertility due to the deterioration of the physical and chemical properties of the soils themselves and air and water regime. Data on the intensity of surface washout on 
the territory of modern Lugansk region for the past century are absent, but modern studies indicate the gradual and steady nature of this process. Currently, about $64 \%$ of agricultural land in Lugansk region suffers from surface erosion. The extent of washout of soils ranges from 30 to $70 \%$. Accordingly, the area with averagely washed out soils is equal to
$15.3 \%$, and with significantly washed out soils $8.6 \%$ of the total area of the region (Kiselova, 2006). Yields on insignificantly washed out soils decrease by $30 \%$, on averagely washed out soils by $30 \%$ to $50 \%$, and on significantly washed out soils by $50 \%$ to $70 \%$ (Medvedyev, 1992).

Table 5. Qualitative state of agricultural lands (Fondovi materialy Golovnogo upravlinnja Derzhgeokadastru v Lugans'kij oblasti, 2016)

\begin{tabular}{|c|l|c|c|}
\hline № & Name of indicator & $\begin{array}{r}\text { Agricultural land, } \\
\text { thousand hectares }\end{array}$ & $\begin{array}{c}\text { Tilled land, } \\
\text { thousand hectares }\end{array}$ \\
\hline 1 & Total agricultural land & 1955.75 & 1276.5 \\
\hline 2 & Saline & 87.9 & 39.7 \\
\hline 3 & Swamps & 15.1 & 1.3 \\
\hline 4 & Stony & 41.7 & 20.2 \\
\hline 5 & Prone to subsidence & 1623.0 & 1265.0 \\
\hline 6 & Eroded & 1195.3 & 902.7 \\
\hline
\end{tabular}

Erosion processes and, in general, soil degradation are reflected in the content of humus in soils. Annual loss of humus is $0.45 \%$. Analysis of data from the State Environmental Protection Agency in Lugansk region over the past 20 years reveals a clear tendency to reduction in the content of humus. One can assume that if in one year this reduction is equal to $0.024 \%$, then in 50 years it will come to $3 \%$. The potential threat of erosion is $5.5 \mathrm{t} / \mathrm{ha} /$ year (Fondovi materialy Derzhavnogo regional'nogo geologorozviduval'nogo pidpryjemstva «Shid-DRGP», 2014).
Despite the different conditions of nature use in the various natural and economic areas of the region (Donetsk ridge - right bank part of the region, Zadonets steppe - the left bank part of the region), the structure of the land in them differs little (Table 6), which given the significant mining pressure on the territory of the right bank, testifies to the greater environmental stress on the pedosphere in this region.

The problems of land use in the southern part of Lugansk region where industrial coal mining been conducted for more than two centuries are catastrophic .

Table 6. The structure of land under natural and economic areas in \% (Fondovimaterialy Golovnogo upravlinnja Derzhgeokadastruv Lugans'kij oblasti, 2016)

\begin{tabular}{|c|l|c|c|c|c|c|c|}
\hline \multirow{2}{*}{ № } & Natural-economic & Agricultural & \multicolumn{4}{|c|}{ Including the: } \\
\cline { 4 - 9 } & & areas & $\begin{array}{c}\text { land } \\
\text { lilled } \\
\text { land }\end{array}$ & $\begin{array}{c}\text { perennial } \\
\text { plantations }\end{array}$ & forage lands & forests & other \\
\hline 1 & Donetsk ridge & 73.5 & 57.2 & 0.9 & 15.2 & 4.9 & 21.8 \\
\hline 2 & Zadonets steppe & 85.4 & 65.2 & 1.0 & 19.2 & 4.6 & 10.0 \\
\hline
\end{tabular}

The direct impact of mining production consists in the burial of soil cover under heaps and dumps, destruction or reduction of agricultural and forest lands, changes in the nature of the surface (in particular, the formation of depression forms of relief, and in areas close to the occurrence of groundwater - waterlogging of the territory), the construction of various man-made structures, laying of communications, etc. Dumps alone in the oblast occupy $4.18 \%$ of the territory.

Indirect effects appear in changes in the regime and the state of surface and groundwater in connection with the flooding of closed mines, the intensification of the infiltration of toxic substances into the soil through the dumps of the «empty» rock, tailings, increasing the volume of water intakes in the river valleys, etc. Due to the drainage of rain through the dumps and heaps, in particular drainage water, and as a result of the temperature rise during combustion of the rock, chemical reactions in the aquatic environment are catalyzed, resulting in the slag heaps affecting locally the deterioration of surface and groundwater, and through them - the physical and chemical properties of soils (Zhulanov, 1981). It should be noted that such indirect influence of the mountain masses raised on the surface, affect the environment at least to an area that is $0.7 \%$ of the area of Lugansk region.

Negative influence of rock dumps, especially when active and smouldering, on soils occurs also through the atmosphere. So, under the influence of flue gases, dust changes the properties of soils, the saturation of particles that settle down from the smoke cloud occurs, and as a result of dust and gases spreading in the soils, the content of trace 
elements increases, the soil and micro flora reactions change, soil compaction changes, and therefore aeration deteriorates. As a result, the structure and chemical composition of soils change.

To date, in Lugansk region, the number of mines, including closed mines and mines under private ownership, is more than 300 . To this one must add about 30 concentrating factories since the latter play the same role in reducing the land stock.

Mining operations within Lugansk region cover an area of over $1,300 \mathrm{~km}^{2}$, mainly on the right bank of the Seversky Donets. The area of mines exceeds $8,000 \mathrm{~km}^{2}$, which accounts for $31 \%$ of the area of coal in the region (Taliev, 1896).

The urgent problem of the coal district in Lugansk region has long been the physical loss of land, that is, the reduction of land resources due to their occupation by dumps of rocks and industrial land structures and communications, which make up more than $4 \%$ of the area of the coal region. Annually in the dumps of mines and concentrating factories 12 million tons of «empty» rocks are accumulated. The total volume of excavated rocks on the surface within Lugansk region is more than 10 billion cubic meters (Taliev, 1896).

For several centuries, large areas under agricultural and forest lands have been destroyed or substantially reduced, and large areas have been involved in various man-made communications facilities. In Lugansk region, the mining industry alone has reduced the land fund of the region by 4,1 $\%$ (Bucik, 1993).

The change in the structure of land indirectly affects the general state of the environment. Thus, during the extraction and enrichment of coal, solid, liquid and gaseous wastes are formed, which constantly replenish the waste heaps, tailing ponds, pollute the atmospheric air, ground water, and the soil itself.

According to the state regional exploration enterprise «East-DRGP», the volume of dumps and heaps increases annually by 1.5 million $\mathrm{m}^{3}$. The total area occupied by the rock mass, concentrated on the surface, is $25.834 \mathrm{~km}^{2}$. The area of influence of dumps and heaps is more than $175 \mathrm{~km}$, or $0.7 \%$ of the area of the region and $2 \%$ of the area of the coal region and 7 times the areas occupied by these artificial formations. The total area affected by mining operations exceeds $30 \%$ of the area of the coal district of Lugansk region (Taliev, 1896).

Conclusions. Literary and archival material provide evidence that the problems of the catastrophic state of the land fund of the Lugansk oblast, in particular agricultural land, have not only failed to diminish, but have deepened over time.

Both intensive and extensive agricultural activity in Lugansk has for centuries led to degradation of land in agriculture due to accelerated anthropogenic erosion, and in mining - due to physical extraction of land due to intensive mine construction and toxicification of soils with mine waters and wastewater from mining rock.

Land use patterns have become damaging features; the use of land in the region has become inefficient and ineffective, and requires the development of new conceptual principles and a systematic approach to the formation of an optimal structure of nature use in general and land use in particular.

In our opinion, the structure of land use should be shaped according to the peculiarities of the natural conditions, in particular, those mentioned above. And this, first of all, must take into account the presence and predominance of slopes, which are erosionally dangerous, and therefore this factor should logically regulate the size of the areas of different types of land.

We are convinced that the current structure of land use in Lugansk region is determined both by natural factors and by the peculiarities and stage of economic development of the region. The inappropriate attitude to natural resources, in particular land, has led to irreversible degradation processes, which makes Lugansk region one of the most ecologically problematic regions of Ukraine.

In developing the strategy of optimal nature management for the IIIrd millennium, one must take into account the whole complex of factors from natural to economic, social and environmental at the state level. Only then will it be possible to move the whole of Ukraine, each of its regions, to sustainable development. For Lugansk region, as well as for Donetsk, synonymous with the tragic events associated with the antiterrorist operation, and now world famous under the name «Donbass», the problem of optimization of land use, restoration of its structure on new conceptual basis is a matter of the greatest urgency.

One of the ways out of the current situation, in addition to monitoring the land currently in use, is in our opinion an immediate revision, diagnosis, soil evaluation, and reclamation of the entire land fund of the region, which requires the use of new techniques, environmentally modern technologies, developed specifically for the specific natural and socio-economic conditions of Lugansk region.

\section{References}

Atlas prirodnih usloviy i estestvennyih resursov Ukrainskoy SSR [Atlas of natural conditions and natural resources of the Ukrainian SSR]. Moscow: 1978 (in Russian). 
Bucik Yu. V., 1993. Obobshenie materialov po tehnogennomu vozdejstviyu ugolnyh shaht na geologo-ekologicheskuyu obstanovku v Ukrainskoj chasti Donbassa [Generalization of materials on the man-caused impact of coal mines on the geological and ecological situation in the Ukrainian part of Donbass]. - K. - 299 p. (in Ukrainian).

Derzhavnij arhiv Luganskoyi oblasti [The State Archive of the Lugansk Region]. - F. R-733, op. 1, sp. 1 (in Ukrainian).

Zhulanov G. A., 1981. Ocenka haraktera i razmerov vrednogo vliyaniya terrikonov na prilegayushie territorii [Estimation of character and size of harmful influence of terricons on adjoining territories]. G. . Zhulanov, G. G. Voznyuk // Protection and rational use of natural resources. Perm. - 32 - 36 p. (in Russian).

Kern E. E., 1928. Ovragi, ih zakreplenie, oblesenie i zapruzhivanie [Landslips, their stabilisation, afforestation and ponding]. E. E. Kern - M. - L.: Gosizdat. - 198 p. (in Russian).

Kiselova O. O., 2006. Problemi ekologichnoyi bezpeki zemelnih resursiv u Luganskij oblasti [Problems of ecological safety of land resources in the Lugansk region]. . . Kiselyova // Regional geographic studies of Ukraine and adjoining territories / Materials of the International. Science-practice Conference devoted to the 70th anniversary of the Formation of the Department of Geography LNPU them. T. Shevchenko (Lugansk, November 27 - 29, 2006). - Lugansk: Alma Mater. - 33 - 35 p. (in Ukrainian).

Lavrenko E. M., 1926. Lesa Doneckogo kryazha [Forests of the Donetsk ridge]. E. M. Lavrenko // Soil Science. - № $3-4$. - 20 - 25 p. (in Russian).

Levakovskij I. F., 1871. O prichinah razlichiya v forme sklonov rechnyh dolin (Dnepra i Dona) [The reasons for the difference in the form of slopes of river valleys (Dnieper and Don)]. I. F. Levakovsky // Proceedings of the Society of Naturalists at the Kharkov University. - T. 3 - X. -32 - 35 p. (in Russian).

Lyashenko P. I., 1952. Istoriya narodnogo hozyajstva SSSR [History of the National Economy of the USSR]. P. I. Lyashchenko - Leningrad: Publishing house of the USSR Academy of Sciences. - 399 p. (in Russian).
Medvedyev V. V., 1992. Do 100-richchya vihodu v svit knigi V. V. Dokuchayeva «Nashi stepi prezhde i teper» [On the 100th anniversary of the publication of the book V. V. Dokuchaev «Our steppes before and now»]. V. V. Medvedev, S. Yu. Buligin // Bulletin of Agrarian Science. - № 4. $-53-55$ p. (in Ukrainian).

Pirko V., 2003. Zaselennya Donechchini u V - V st. [Population of Donetsk region in the seventeenth and eighteenth centuries]. Vasyl Pirko. - Donetsk. - 25 - 26 p. (in Ukrainian).

Podov V. I., 2004. Istoriya Donbassa: V 3-h t. - T. 1. Donbass V V - V vekah [The history of Donbass: In 3 t. - T. 1. - Donbass in the Seventeenth and Eighteenth centuries]. V. I. Podov - Lugansk: Alma Mater. - 336 p. (in Russian).

Rozov N. A., 1927. Ovragi Ukrainy. Materialy po ovrazhno-peschanomu voprosu Ukrainy [The ravines of Ukraine. Materials on the ravine-sand question of Ukraine]. N. . Rozov. - K. -61 p. (in Russian).

Taliev V. I., 1896. Rastitelnost krajnego yugovostochnogo punkta Ekaterinoslavskoj gubernii [Vegetation of the extreme southeastern point of Ekaterinoslav province]. V. I. Taliev // Proceedings of the Society of Naturalists at Kharkov University. - 15 - 26 p. (in Russian).

Fondovi materialy Golovnogo upravlinnja Derzhgeokadastru v Lugans'kij oblasti [Stock Materials of the Main Department of the State Service for Geodesy, Cartography and Cadastre of Ukraine in the Lugansk region]. - 2016 (in Ukrainian).

Fondovi materialy Derzhavnogo regional'nogo geologorozviduval'nogo pidpryjemstva «ShidDRGP» [ Archival Materials of the State Regional Exploration Enterprise «East-DRHP»]. - 2014 (in Ukrainian).

Shikula N. K., 1961. Razvitie erozionnyh processov v Donbasse [The development of erosion processes in the Donbas]. N. K. Shikula // Natural resources of the left-bank Ukraine and their use. Interdepartmental materials. sci. Confer. - T. II. Kh .: Kharkov Publishing House. University. $332-338$ p. (in Russian). 